\title{
Neuroinflammation in autism spectrum disorders
}

\author{
Afaf El-Ansary ${ }^{1,2,3,5^{*}}$ and Laila Al-Ayadhi ${ }^{2,3,4}$
}

\begin{abstract}
Objectives: The neurobiological basis for autism remains poorly understood. However, research suggests that environmentalfactors and neuroinflammation, as well as genetic factors, are contributors. This study aims to test the role that might be played by heat shock protein (HSP)70, transforming growth factor (TGF)- $\beta_{2}$, Caspase 7 and interferon- $\gamma$ (IFN- - ) in the pathophysiology of autism.

Materials and methods: HSP70, TGF- $\beta_{2}$, Caspase 7 and INF- $\gamma$ as biochemical parameters related to inflammation were determined in plasma of 20 Saudi autistic male patients and compared to 19 age- and gender-matched control samples.

Results: The obtained data recorded that Saudi autistic patients have remarkably higher plasma HSP70, TGF- $\beta_{2}$, Caspase 7 and INF- $\gamma$ compared to age and gender-matched controls. INF- $\gamma$ recorded the highest (67.8\%) while TGF- $\beta$ recorded the lowest increase (49.04\%). Receiver Operating Characteristics (ROC) analysis together with predictiveness diagrams proved that the measured parameters recorded satisfactory levels of specificity and sensitivity and all could be used as predictive biomarkers.

Conclusion: Alteration of the selected parameters confirm the role of neuroinflammation and apoptosis mechanisms in the etiology of autism together with the possibility of the use of HSP70, TGF- $\beta_{2}$, Caspase 7 and INF- $\gamma$ as predictive biomarkers that could be used to predict safety, efficacy of a specific suggested therapy or natural supplements, thereby providing guidance in selecting it for patients or tailoring its dose.
\end{abstract}

Keywords: Autism, Neuroinflammation, Heat shock protein-70, Transforming growth factor- $\beta$, Interferon- $\gamma$, Caspase7

\section{Introduction}

Autism is a complex neurodevelopmental disorder of early onset that is highly variable in its clinical presentation. Although the causes of autism in most patients remain unknown, several lines of research support the view that susceptibility to autism is clearly attributed to both genetic and environmental factors that influence the development of abnormal cortical circuitry that underlies autistic cognitive processes, social impairment and other behaviors [1]. Additionally, recent evidence points to inflammatory mechanisms contributing toautism. Vargas et al. [2] suggested neuroinflammatory processes are present in the autistic brain by showing that transforming growth factor (TGF- $\beta_{1}$ ), interleukin (IL) 6 and IL10 are increased in the brain of autistic patients. A number of studies have also shown that inflammatory

\footnotetext{
* Correspondence: elansary@ksu.edu.sa

1 Biochemistry Department, Science College, King Saud University, P.O. Box 22452, 11495 Riyadh, Saudi Arabia

${ }^{2}$ Autism Research and Treatment Center, Riyadh, Saudi Arabia

Full list of author information is available at the end of the article
}

cytokines, including tumor necrosis factor (TNF) $\alpha$, interferon (IFN) $\gamma$, IL1, IL6, IL8 and IL12, are elevated in blood mononuclear cells, serum, plasma and cerebrospinal fluid (CSF) of autistic subjects [2-8].

The role of extracellular $70 \mathrm{kDa}$ heat shock protein 70 (HSP70) in central nervous system inflammation is vastly understudied, despite evidence supporting its ability to drive a pro-inflammatory state [9]. Heat shock proteins (HSPs) are induced in response to many injuries including stroke, neurodegenerative disease, epilepsy and trauma. The overexpression of HSP70 serves a protective role in several different models of nervous system injury, but has also been linked to a deleterious role in some diseases [10].

The transforming growth factor- $\beta$ (TGF- $\beta$ ) superfamily is a multifunctional family of cytokines that has a critical role in the regulation of key events of development, disease and tissue repair in the nervous system. Accumulating evidence suggests that TGF- $\beta$ has emerged as a crucial regulator of nervous system physiology, although it has been widely considered as an injury-

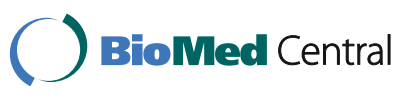


related cytokine [11]. It is still unclear whether plasma TGF- $\beta$ levels could reflect its brain concentration since it is shown that it can cross the disrupted but not the intact blood-brain barrier (BBB) [12].

It is well known that activation of cysteinyl aspartatespecific proteases (caspases) may underlie apoptotic cell death in the brain. Caspase 3, 6 and 7 likely contribute to such cell death in a stimulus- and cell type-specific manner [13]. Recent studies proved the activation of caspases 3, 7 and 12 in peripheral blood mononuclear cells (PBMCs) from 15 autistic children compared to agematched normal healthy developing controls [14] In addition, El-Ansary et al. [8] recorded an elevation of Caspase 3 in plasma of Saudi autistic children compared to control subjects.

In a study done by Li et al. [15], the immune activities in the brain of autistic patients were significantly higher compared to matched normal subjects. Proinflammatory cytokines (TNF- $\alpha$, IL-6), Th1 cytokine (IFN- $\gamma$ ) were the most significantly increased.

Considering the protective and/or the deleterious effect of HSP70, the key role of TGF- $\beta$ in brain development [11], the possible role of caspase pathway, and the suggested role of localized brain inflammation and autoimmunity in the pathology of autism, it is of great interest to measure these parameters in plasma of the Saudi population compared to controls in an attempt to understand and clarify their roles in the etiology of this disorder.

\section{Subjects and methods}

The study protocol followed the ethical guidelines of the most recent Declaration of Helsinki (Edinburgh, 2000). All 20 autistic subjects enrolled in the study had written informed consent provided by their parents and assented to participate if developmentally able. Subjects for this study were enrolled through the ART Center (Autism Research and Treatment Center) clinic. The ART Center clinic sample population consisted of children diagnosed with Autism Spectrum Disorder (ASD). The diagnosis of ASD was confirmed in all subjects using the Autism Diagnostic Interview-Revised (ADI-R) and the Autism Diagnostic Observation Schedule (ADOS) and 3DI (Developmental, dimensional diagnostic interview). The ages of all autistic children ranged between 3 and 16 years old. All were non-verbal males. Intelligence quotient (IQ) for all autistic children was below 80 . All were simplex cases. All are negative for fragile $\times$ gene study. The 19 healthy control subjects were recruited from the well-baby clinic at King Khaled University Hospital and they were 3 to 16 years old. All participating subjects were excluded from the investigation if they had dismorphic features, tuberous sclerosis, Angleman syndrome, or other serious neurological (for example, seizures), psychiatric (for example, bipolar disorder) or known medical conditions. All participants were screened via parental interview for current and past physical illness. Children with known endocrine, cardiovascular, pulmonary, liver, kidney or other medical disease were excluded from the study.

\section{Ethics approval and consent}

This work was ethically approved by the ethical committee of King Khalid Hospital, King Saud University (Approval number is $11 / 2890 / \mathrm{IRB}$ ). A written consent was obtained from the parents of each individual case, according to the guidelines of the ethical committee.

\section{Samples collection}

After an overnight fast, $10 \mathrm{ml}$ blood samples were collected from both groups in test tubes containing heparin as an anticoagulant. Centrifugation was done; plasma was obtained and deep frozen $\left(\right.$ at $\left.-80^{\circ} \mathrm{C}\right)$ until analysis time.

\section{Chemicals and kits}

All chemicals and kits used in this study were of analytical grade, a product of Sigma-Aldrich Corp, St Louis, USA. Uscn LifeScience Inc, Wuhan, China; Quantikine, R \& D Systems, Inc, Minneapolis, USA and Thermoscientific (Rockford, IL, USA).

\section{Biochemical assays}

\section{Assay of heat shock protein 70 (HSP70)}

HSP70 was measured using an ELISA kit, product of Uscn Life Science Inc., Wuhan, China, according to the manufacturer's instructions. The microtiter plate provided in this kit has been pre-coated with an antibody specific for HSP70. Standards or samples are then added to the appropriate microtiter plate wells with a biotinconjugated polyclonal antibody preparation specific for HSP70. Next, avidin conjugated to horseradish peroxidase (HRP) is added to each microplate well and incubated for two hours at $37^{\circ} \mathrm{C}$. Then, a 3,3', 5,5' tetramethylbenzidine (TMB) substrate solution is added to each well. Only those wells that contain HSP70, biotin-conjugated antibody and enzyme-conjugated avidin will exhibit a change in color. The enzymesubstrate reaction is terminated by the addition of a sulfuric acid solution and the color change is measured spectrophotometrically at a wavelength of $450 \mathrm{~nm} \pm 10$ $\mathrm{nm}$. The concentration of HSP70 in the samples is then determined by comparing the optical density of the samples to the standard curve. The minimum detectable level of HSP70 detected is less than $0.045 \mathrm{ng} / \mathrm{ml}$. 
Table 1 HSP70 (ng/ml), TGF- $\beta$ (pg/ml), Caspase-7 (ng/ml) and INFY ( $\mathrm{ng} / \mathrm{ml})$ of control and autistic groups

\begin{tabular}{lllll}
\hline Parameters & Groups & N & Mean \pm S.D. & $P$-value \\
\hline HSP70 $(\mathrm{ng} / \mathrm{ml})$ & Control & 19 & $10.17 \pm 2.05$ & 0.001 \\
& Autistic & 20 & $15.82 \pm 2.21$ & \\
TGF- $\beta(\mathrm{pg} / \mathrm{ml})$ & Control & 19 & $68.30 \pm 10.35$ & 0.001 \\
& Autistic & 20 & $101.80 \pm 8.86$ & \\
Caspas-7 (ng/ml) & Control & 19 & $5.63 \pm 1.07$ & 0.001 \\
& Autistic & 20 & $8.74 \pm 1.43$ & \\
INF- $(\mathrm{ng} / \mathrm{ml})$ & Control & 19 & $50.85 \pm 5.71$ & 0.001 \\
& Autistic & 20 & $85.33 \pm 9.06$ & \\
\hline
\end{tabular}

Table 1 describes the independent T-Test between the control and autistic groups in HSP70 (ng/ml), TGF- $\beta$ (pg/ml), Caspase-7 (ng/ml) and INF- $\gamma(\mathrm{ng} / \mathrm{ml})$.

\section{Assay of TGF- $\beta_{2}$}

The Quantikine Human TGF- $\beta_{2}$ ELISA kit used in the present study is designed to measure activated TGF- $\beta_{2}$ in serum and plasma. A monoclonal antibody specific for TGF- $\beta_{2}$ has been pre-coated onto a microplate. A total of $100 \mu \mathrm{l}$ standards and samples were pipetted to each well and incubated for two hours at room temperature. After washing away any unbound sub-

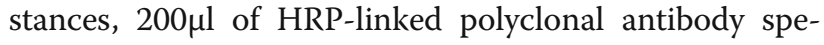
cific for TGF- $\beta_{2}$ is added to the wells. Following a wash to remove any unbound antibody-enzyme reagent, a $200 \mu \mathrm{l}$ substrate solution is added to the wells and color develops in proportion to the amount of TGF- $\beta_{2}$ bound in the initial step. The color development is stopped using $50 \mu \mathrm{l}$ stop solution and the intensity of the color was measured within 30 minutes at $540 \mathrm{~nm}$. The minimum detectable level of TGF- $\beta_{2}$ is less than $7.0 \mathrm{pg} / \mathrm{ml}$.

\section{Assay of Caspase7 (CASP7)}

CASP7 was measured using an ELISA kit, a product of Uscn Life Science Inc., Wuhan, China, according to the manufacturer's instructions. The microtiter plate provided in this kit has been pre-coated with an antibody specific to CASP7. Standards or samples are then added to the appropriate microtiter plate wells with a biotin-conjugated polyclonal antibody preparation specific for CASP7 and incubated for two hours at room temperature. Next, avidin conjugated to HRP is added to each microplate well and incubated. Then a TMB substrate solution is added to each well. Only those wells that contain CASP7, biotin-conjugated antibody and enzyme-conjugated avidin will exhibit a change in color. The enzyme-substrate reaction is terminated by the addition of a sulphuric acid solution and the color change is measured spectrophotometrically at a wavelength of $450 \mathrm{~nm}^{2} \mathrm{~nm}$. The concentration of CASP7 in the samples is then determined by comparing the O.D. of the samples to the standard curve. The minimum detectable level of CASP7detected is less than $0.065 \mathrm{ng} / \mathrm{ml}$.

\section{Assay of IFNY}

IFN $\gamma$ was measured using an ELISA kit, a product of Thermo Scientific (Rockford, IL, USA) according to the manufacturer's instructions. This assay employs a quantitative sandwich enzyme immunoassay technique that measures IFN $\gamma$ in less than five hours. A polyclonal antibody specific for human IFN $\gamma$ has been pre-coated onto a 96-well microplate. IFN $\gamma$ in standards and samples is sandwiched by the immobilized antibody and biotinylated polyclonal antibody specific for IFN $\gamma$, which is recognized by a streptavidin-peroxidase conjugate. All unbound material is then washed away and a peroxidase enzyme substrate is added. The color development is stopped and the intensity of the color is measured at $550 \mathrm{~nm}$ and subtracted from absorbance at $450 \mathrm{~nm}$. The minimum level of IFN $\gamma$ detected by this product is less than $2 \mathrm{pg} / \mathrm{ml}$.

\section{Statistical analysis}

A SPSS (Statistical Package for the Social Sciences computer program was used. Results were expressed as mean \pm S.D. and all statistical comparisons were made by means of independent t-test with $P \leq 0.05$ considered as significant. ROC analysis was performed. Area under the curve, cutoff values selected by the program together

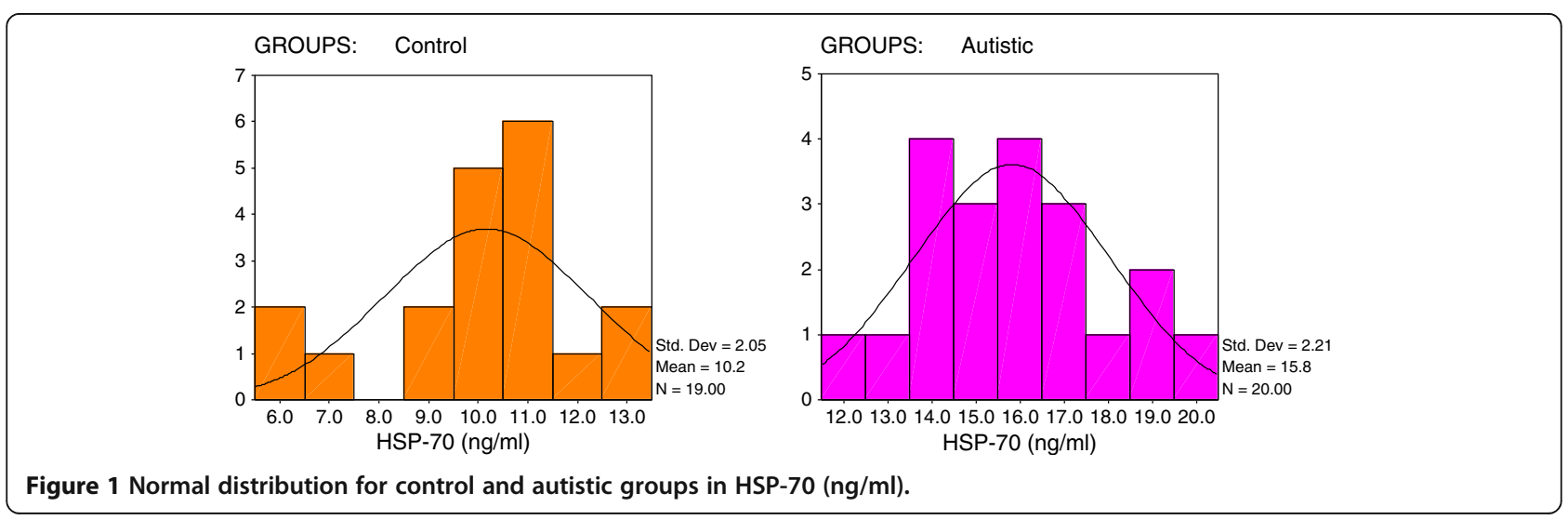



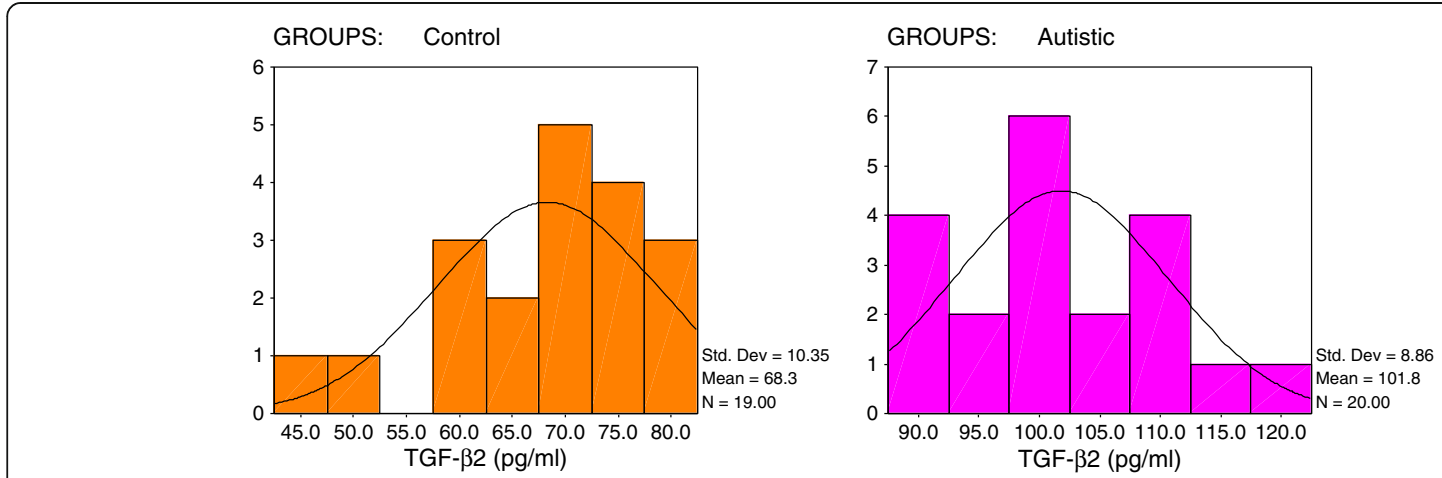

Figure 2 Normal distribution for control and autistic groups in TGF- $\beta$ (pg/ml).

with degree of specificity and sensitivity were calculated. Moreover, the predictiveness diagrams of the four measured parameters were drawn in which the $x$ axis represents percentile rank of the biomarker, $y$ axis represents the probability of identifying the disease and the horizontal line is the prevalence of the disease using a Biostat 16 computer program.

\section{Results}

Table 1 and Figures 1, 2, 3, 4 demonstrate the significant increase of the four measured parameters in autistic patients compared to healthy age- and gender-matched control subjects. Figure 1 shows that 19/20 of the autistic samples recorded a HSP-70 concentration greater than $12 \mathrm{ng} / \mathrm{ml}$ while $16 / 19$ of the controls show values remarkably lower than this value. All autistic patients recorded values greater than $80 \mathrm{pg} / \mathrm{ml}$ or $7.5 \mathrm{ng} / \mathrm{ml}$ as the maximum concentration seen in control subjects for TGF- $\beta$ and Caspase-7, respectively (Figures 2 and 3). Additionally, 10/20 of autistics recorded concentrations of INF- $\gamma$ greater than $85 \mathrm{ng} / \mathrm{ml}$ while $15 / 19$ of the controls show values lower than $57.5 \mathrm{ng} / \mathrm{ml}$ (Figure 4).

Figure 5 demonstrate the percentage increase in the measured parameters. It could be easily noticed that INF- $\gamma$ recorded the highest increase $(67.8 \%)$ while TGF- $\beta 2$ recorded the lowest increase (49.04\%). Table 2 and Figures 6 and 7 demonstrate the ROC analysis of the measured parameters (area under the curve, specificity and sensitivity).

Figure 8 shows the predictiveness diagrams of the four measured parameters in relation to the prevalence of autism in Saudi Arabia, which was most recently recorded as 18 per 10,000 persons [16].

\section{Discussion}

In a recent hypothesis proposed by Theoharides and Zhang [17], an association among neuroinflammation, mast cell activation and seizures, through secretion of pro-inflammatory mediators and regulation of the $\mathrm{BBB}$ permeability was suggested. Despite a large amount of research, the pathogenic mechanism of autism has not yet been clarified. Abnormal protein folding $[17,18]$ oxidative stress [19], mitochondrial dysfunction [20], and apoptotic mechanisms [8] have all been reported as causes of neurodegeneration in association with neuroinflammatory mechanisms which, by generating deleterious molecules, could promote the cascade of events leading to autism. Heat shock proteins (HSPs) play a central role in preventing protein misfolding and
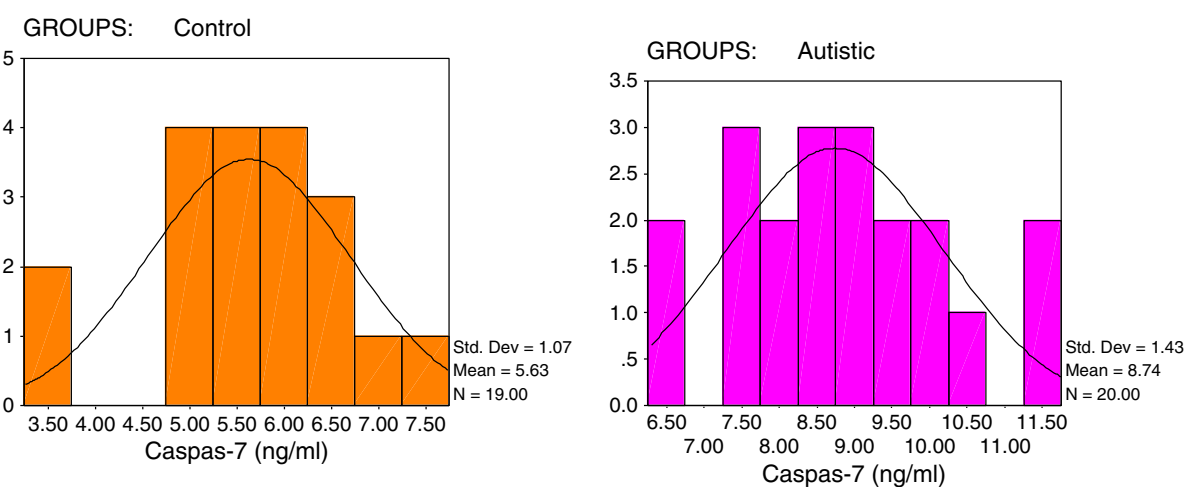

Figure 3 Normal distribution for control and autistic groups in Caspase-7 (ng/ml). 

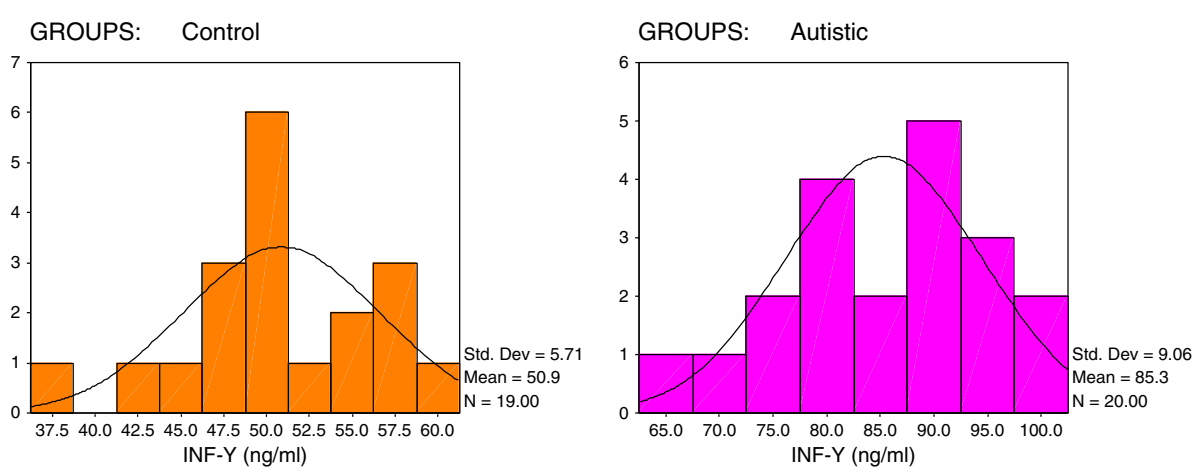

Figure 4 Normal distribution for control and autistic groups in INF- $\gamma(\mathrm{ng} / \mathrm{ml})$.

inhibiting apoptotic activity, and represent a class of proteins potentially involved in neurological disorders [10].

The significant increase in HSP70 reported in the present study could be easily related to oxidative stress as the most important mechanism involved in the etiology of autism. In spite of the protective role of HSPs, they are only effective when up-regulated in the right place (that is, be cell specific), at the right time and to a level and specificity that ensures that all the important binding partners, namely the co-chaperones, are also present at the appropriate levels [21]. So, even though heat shock proteins are known to inhibit various types of apoptosis, some studies show that heat or elevated HSP70 also potentiates cell death following specific stimuli. The unexpected elevation of HSP70 could be related to the etiology of autism by considering the fact that HSP70 initiates TNF-mediated apoptosis by binding I $\kappa B$ kinase (IKK) and impairing nuclear factor-kappaB (NF-kB) survival signaling due its inactivation after being phosphorylated [22]. This explanation could be supported through considering the recent work of ElAnsary et al. [8], in which they recorded a significantly lower TNF- $\alpha$ in the same plasma samples used for the current study. Moreover, a number of studies have also shown that heat shock or elevated HSP70 suppresses
NF- $\mathrm{BB}$ activity[23-27].Although these studies imply the possibility that HSP70 impairs NF-kB signaling, the exact molecular basis of the Hsp70 and NF- $\mathrm{kB}$ interaction is still not clarified. Elevation of HSP70 reported in the present study could be supported and related to the heavy metal toxicity (mercury) and the inability to adequately up-regulate metallothionein (MT) biosynthesis in response to the heavy metal challenge by autistic patients, which was recently recorded in the same investigated samples (unpublished work). Cultured lymphocytes from autistic children when challenged with 10 $\mu \mathrm{M}$ ethyl mercury responded in a different pattern than those of non-autistic siblings. Following the challenge, autistic cultured lymphocytes responded by upregulating numerous heat shock protein transcripts, but not MTs [28].

The remarkable increase of TGF- $\beta_{2}$ in plasma of autistic patients reported in the present study could be related to brain injury in autism because it is well known that this cytokine is expressed in the lesioned brain [9] and is up-regulated in the central nervous system following ischemia-induced brain damage $[29,30]$. Although TGF- $\beta_{2}$ is often considered an anti-inflammatory molecule, we could propose that enhanced TGF- $\beta_{2}$ expression may play a certain role in promoting

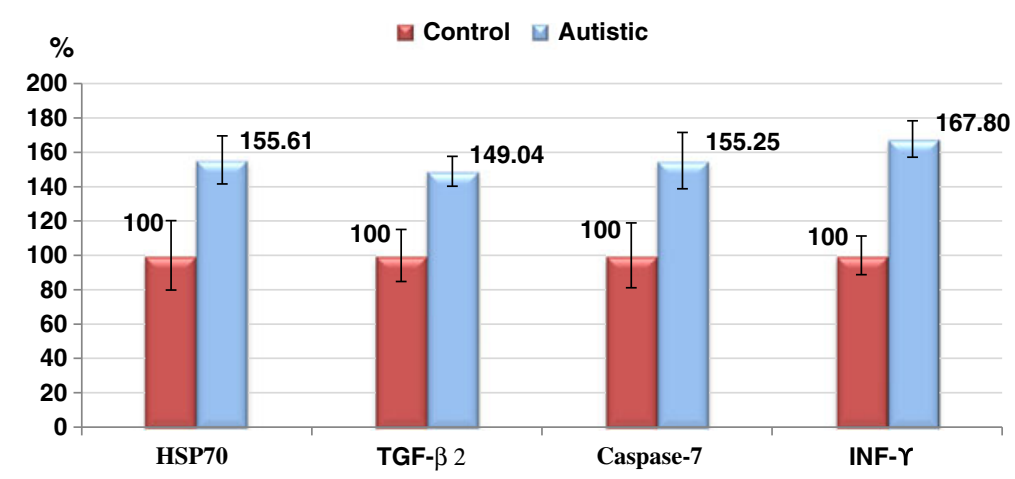

Figure 5 Percentage change of HSP-70 (ng/ml), TGF- $\beta$ (pg/ml), Caspase-7 (ng/ml) and INF- $\gamma(\mathrm{ng} / \mathrm{ml})$ in the autistic group compared to control. 
Table 2 ROC analysis of the measured parameters shows, area under the curves, specificity and sensitivity

\begin{tabular}{lllll}
\hline Parameter & Area under the curve & Cutoff value & Sensitivity \% & Specificity \% \\
\hline HSP-70 $(\mathrm{ng} / \mathrm{ml})$ & 0.987 & 12.218 & $95.0 \%$ & $84.2 \%$ \\
TGF- $\beta(\mathrm{pg} / \mathrm{ml})$ & 1.000 & 78.649 & $100.0 \%$ & $89.5 \%$ \\
Caspase-7 $(\mathrm{ng} / \mathrm{ml})$ & 0.968 & 6.698 & $90.0 \%$ & $89.5 \%$ \\
INF- $\gamma(\mathrm{ng} / \mathrm{ml})$ & 1.000 & 56.558 & $100.0 \%$ & $78.9 \%$ \\
\hline
\end{tabular}

inflammation in brain injury associated with autism. Because TGF- $\beta_{1}$ and TGF- $\beta_{2}$ exhibit a combination of specific and shared roles in the regulation of inflammation, this suggestion could find a support in the previous work which indicates that injection of an antiserum directed against TGF- $\beta_{1}$ reduces inflammation in the CNS after traumatic injury, and astroglial overproduction of TGF- $\beta_{1}$ enhances inflammatory CNS disease in transgenic mice [31-33]. The elevated TGF- $\beta_{2}$ reported in the present study is in good agreement with the previous work of Vargas et al. [2] in which they found TGF$\beta_{1}$ among the neuroinflammatory cytokines elevated in the cerebral cortex, white matter and notably in the cerebellum of autistic patients. The recorded increase of plasma TGF- $\beta_{2}$ as a marker of elevated TGF- $\beta_{2}$ in the brain could be easily related to amyloid beta $(A \beta)$ generation previously recorded in autistic patients [34,35]. This could be supported through considering the work of Lesne et al. [36], in which they show that TGF- $\beta_{1}$ added to human astrocyte cultures promotes perivascular inflammation, interactions with and increased production of amyloid beta precursor protein $(\mathrm{A} \beta \mathrm{PP})$ and subsequent $A \beta$ generation.

Caspases as a family of cysteine proteases play central roles in coordinating the stereotypical events that occur during apoptosis. Because the major executioner caspases, Caspase- 3 and Caspase-7, exhibit the most potent activity toward certain synthetic peptide substrates, this has led to the widespread view that both occupy critical roles within the cell death machinery [37]. Additionally, Erener et al. [38] propose an apoptosis-independent regulatory role for Caspase 7-mediated cleavage of poly (ADP-ribose) polymerase family, member 1 (PARP1) as a DNA repair-associated enzyme that has multiple roles in cell death. The significant elevation of Caspase 7 reported in the present study could be easily related to the impaired NF- $\mathrm{kB}$ signaling survival activity as previously attributed to HSP70 but through a different mechanism. Elevation of Caspase 7 again confirms the contribution of brain cell death and proinflammation in the etiology of autism as previously reported in our recent work in 2011 [8], in which Caspase 3 as a proapoptotic biomarker was significantly lower in plasma which might indicate its increase in the brain of Saudi autistic patients compared to age- and gender-matched controls. Moreover, both studies are consistent with the most recent work of Siniscalco et al. [14] in which they prove the increase of protein levels of caspase-3, - 7 and -12 in autistic patients and suggest the possible role of the caspase pathway in autism clinical presentation and the use of caspases as potential diagnostic and/or therapeutic tools.

Immune factors, such as autoimmunity, have been implicated in the genesis of autism [3].The increase of IFN- $\gamma$ reported in the present study may indicate antigenic stimulation of Th-1 cells pathogenetically linked to autoimmunity in autism. The reported elevation of IFN$\gamma$ could support the previous work of Molloy et al. [5]

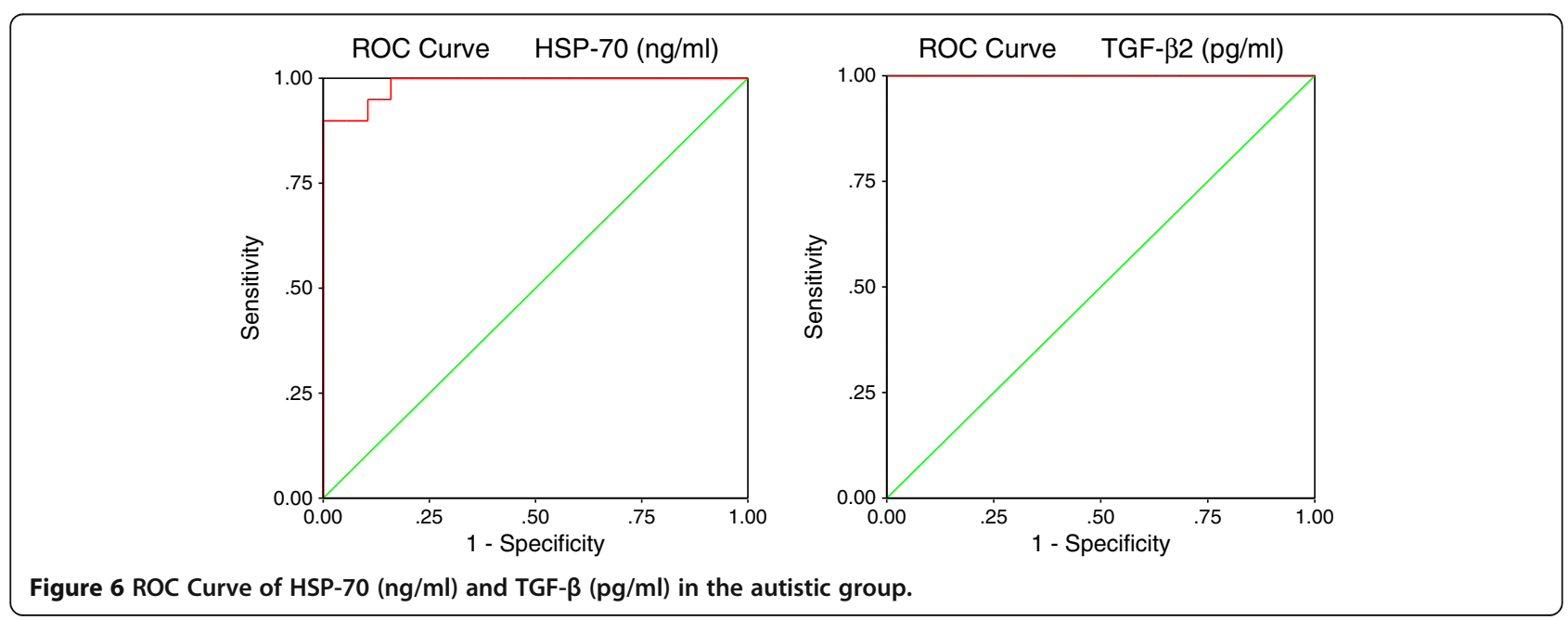




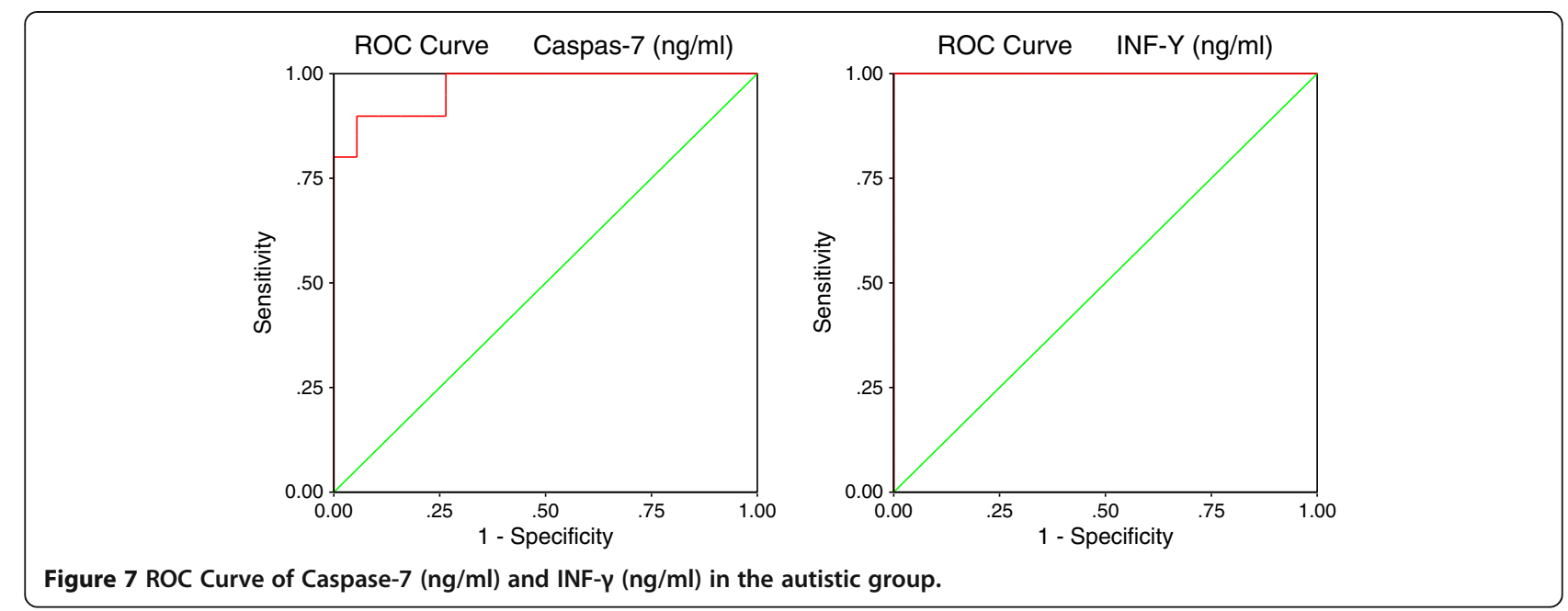

showing that PBMNC of autistic children produce remarkably high levels of Il-12 and IFN- $\gamma$, or express higher than normal levels of mRNA for IFN- $\gamma$ [39] and the most recent work of Tostes et al. [40] that plasma levels of vasoactive intestinal peptide (VIP), IFN- $\gamma$ and NO were significantly higher in children with autism, compared to the healthy subjects and that a positive correlation between plasma levels of $\mathrm{NO}$ and IFN- $\gamma$ exists. Moreover, they suggested additional evidence that higher levels of IFN- $\gamma$ may be associated with increased oxidative stress, a phenomenon greatly involved in the etiology of autism [19]. Collectively, the present study together with the previously mentioned studies confirm the existence of Th-1 type of immune response in

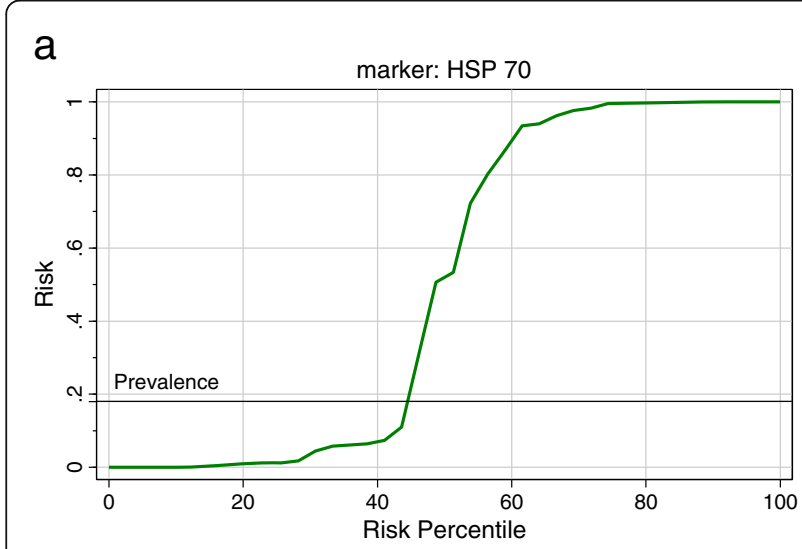

b

C
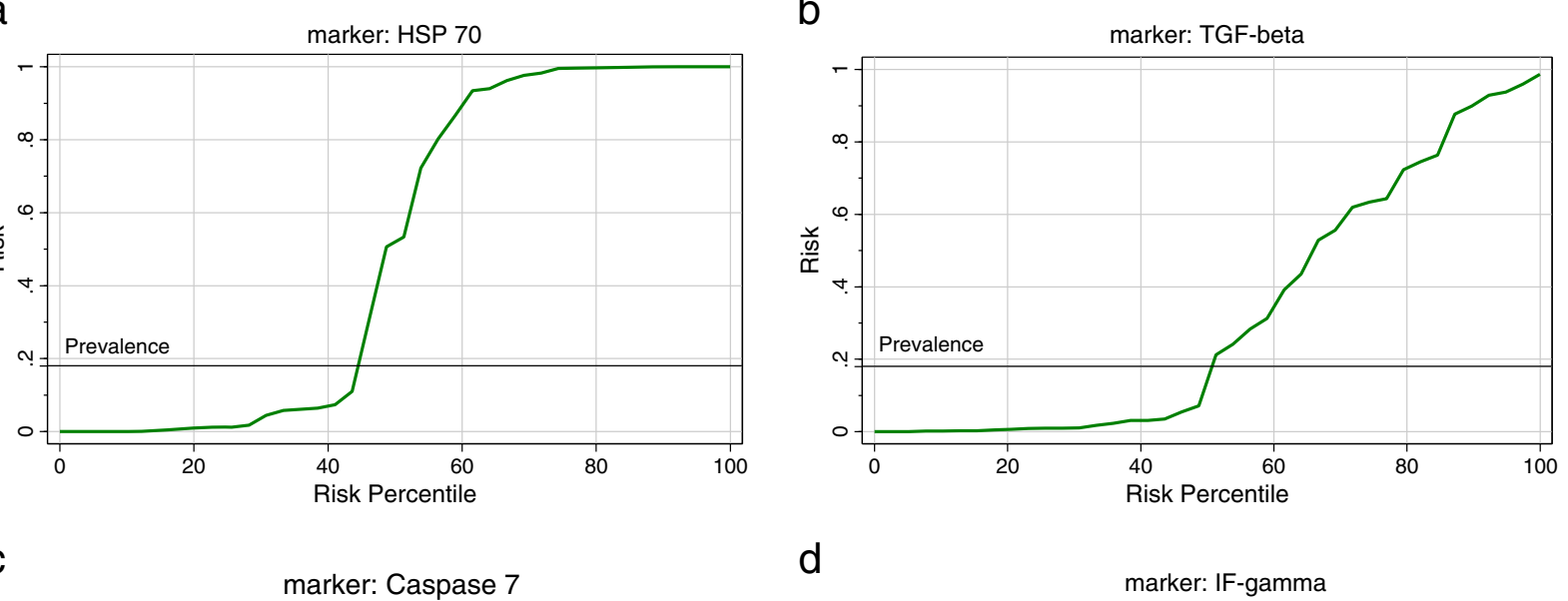

d
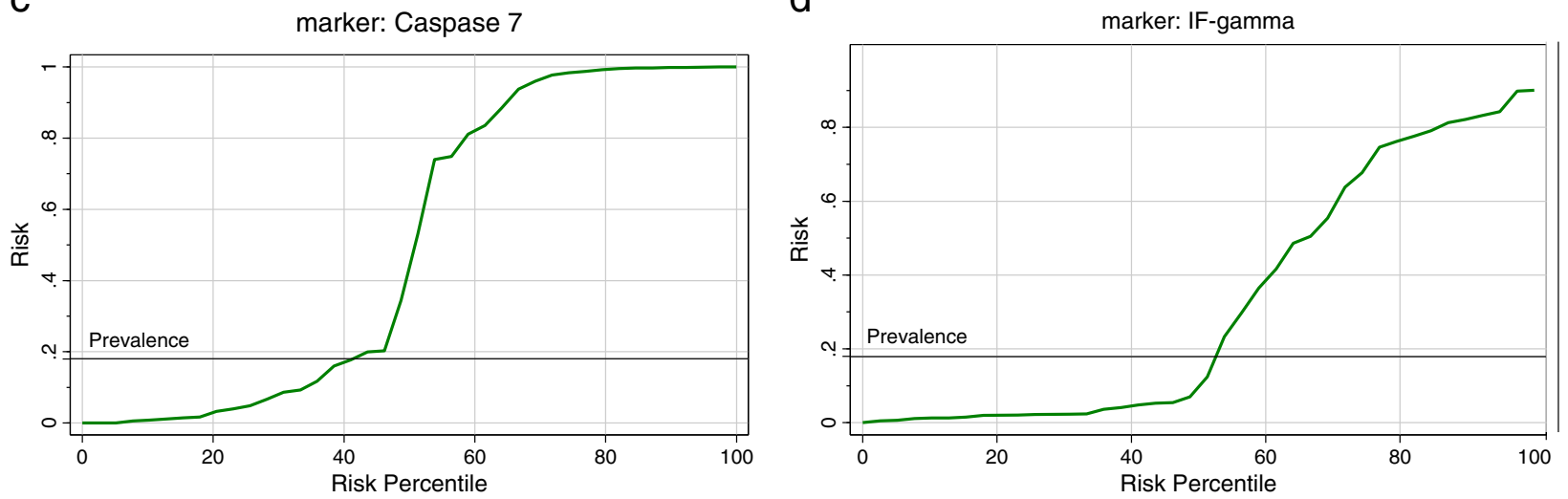

Figure 8 Predictivness diagrams of the four studied parameters in relation to autism prevalence in Saudi Arabia. 
autistic children and that would also be consistent with an autoimmune pathology, simply because IFN- $\gamma$ is among the cytokines well known for inducing autoimmune diseases. Based on the fact that the predictiveness curve is better if it is farther away from the prevalence line and useless if it is close to the prevalence line, the predictiveness curves of the four measured parameters (Figure $8 \mathrm{a}-\mathrm{d}$ ), varies significantly from the baseline risk depending on whether HSP70, TGF- $\beta_{2}$,Caspase 7 and IFNY concentrations were low or very high. This shows their usefulness as predictive biomarkers. This could be supported by the high sensitivity and specificity recorded through ROC analysis (Figures 6 and 7).

\section{Abbreviations}

Aß: Amyloid beta; ADI-R: Autism Diagnostic Interview-Revised; HSP-70: Heat shock protein-70; IFN- $\gamma$ : Interferon- $\gamma$; TGF- $\beta$ : Transforming growth factor- $\beta$; TNF-a: Tumor necrosis factor- $\alpha$; ROC: Reciever Operating Characteristics.

\section{Competing interests}

The authors declare that they have no competing interests.

\section{Authors' contributions}

AE designed the study and drafted the manuscript. LA provided samples and participated in the diagnosis of the autistic samples. Both authors have read and approved the final manuscript.

\section{Acknowledgements}

The authors would like to thank Shaik AL-Amodi Autism Research Chair NPST - Medical Centers and the parents of autistic children, without whom this work was not possible. This work was supported by King Abdul Aziz City for Science and Technology (KACST).

\section{Author details}

${ }^{1}$ Biochemistry Department, Science College, King Saud University, P.O. Box 22452, 11495 Riyadh, Saudi Arabia. ${ }^{2}$ Autism Research and Treatment Center, Riyadh, Saudi Arabia. ${ }^{3}$ Shaik AL-Amodi Autism Research Chair, King Saud University, Riyadh, Saudi Arabia. ${ }^{4}$ Department of Physiology, Faculty of Medicine, King Saud University, Riyadh, Saudi Arabia. ${ }^{5}$ Medicinal Chemistry Department, National Research Centre, Dokki, Cairo, Egypt.

Received: 13 October 2012 Accepted: 28 November 2012 Published: 11 December 2012

\section{References}

1. Abrahams BS, Geschwind DH: Advances in autism genetics: on the threshold of a new neurobiology. Nat Rev Genet 2008, 9:341-355.

2. Vargas DL, Nascimbene C, Krishnan C, Zimmerman AW, Pardo CA Neuroglial activation and neuroinflammation in the brain of patients with autism. Ann Neurol 2005, 57:67-81.

3. Singh VK: Plasma increase of interleukin-12 and interferon-gamma: pathological significance in autism. J Neuroimmunol 1996, 66:143-145.

4. Croonenberghs J, Bosmans E, Deboutte D, Kenis G, Maes M: Activation of the inflammatory response system in autism. Neuropsychobiology 2002, 45(suppl 1):1-6.

5. Molloy CA, Morrow AL, Meinzen-Derr J, Schleifer K, Dienger K, ManningCourtney P, Altaye M, Wills-Karp M: Elevated cytokine levels in children with autism spectrum disorder. J Neuroimmunol 2006, 172:198-205.

6. Ashwood P, Wakefield AJ: Immune activation of peripheral blood and mucosal CD3a lymphocyte cytokine profiles in children with autism and gastrointestinal symptoms. J Neuroimmunol 2006, 173:126-134.

7. Chez MG, Burton Q, Dowling T, Chang M, Khanna P, Kramer C: Memantine as adjunctive therapy in children diagnosed with autistic spectrum disorders: an observation of initial clinical response and maintenance tolerability. J Child Neurol 2007, 22:574-579.
8. El-Ansary A, Ben Bacha AG, Al-Ayadhi LY: Proinflammatory and proapoptotic markers in relation to mono and di-cations in plasma of autistic patients from Saudi Arabia. J Neuroinflammation 2011, 8:142.

9. Moore SA, Kim MY, Maiolini A, Tipold A, Oglesbee MJ: Extracellular hsp70 release in canine steroid responsive meningitis-arteritis. Vet Immunol Immunopathol 2012, 145:129-133.

10. Turturici G, Sconzo G, Geraci F: Hsp70 and its molecular role in nervous system diseases. Biochem Res Int 2011, 2011:618127.

11. Gomes FCA, Sousa Vde O, Romao L: Emerging roles for TGF- $\beta 1$ in nervous system development. Int J Dev Neurosci 2005, 23:413-424.

12. Kastin AJ, Akerstrom $V$, Pan W: Circulating TGF-beta1 does not cross the intact blood-brain barrier. J Mol Neurosci 2003, 21:43-48.

13. Meller R, Skradski SL, Simon RP, Henshall DC: Expression, proteolysis and activation of caspases 6 and 7 during rat C 6 glioma cell apoptosis. Neurosci Lett 2002, 324:33-36.

14. Siniscalco D, Sapone A, Giordano C, Cirillo A, de Novellis V, de Magistris L, Rossi F, Fasano A, Maione S, Antonucci N: The expression of caspases is enhanced in peripheral blood mononuclear cells of autism spectrum disorder patients. J Autism Dev Disord 2012, 42:1403-1410.

15. Li X, Chauhan A, Sheikh AM, Patil S, Chauhan V, Li XM, Ji L, Brown T, Malik M: Elevated immune response in the brain of autistic patients. J Neuroimmunol 2009, 207:111-116

16. El-Tarras AE, Awad NS, Mitwaly N, Alsulaimani AA, Said MM: Association between polymorphisms of SLC6A3 and DRD1 genes and autism among Saudi Arabia Taif population using PCR-restriction fragment length polymorphism (PCR- RFLP). Afr J Biotechnol 2012, 11:11665-11670.

17. Theoharides TC, Zhang B: Neuro-inflammation, blood-brain barrier, seizuresand autism. J Neuroinflammation 2011, 8:168.

18. De Jaco A, Comoletti D, Kovarik Z, Gaietta G, Radic Z, Lockridge O, Ellisman $\mathrm{MH}$, Taylor $\mathrm{P}$ : A mutation linked with autism reveals a common mechanism of endoplasmic reticulum retention for the alpha, betahydrolase fold protein family. J Biol Chem 2006, 281:9667-9676.

19. Al-Gadani Y, El-Ansary A, Attas O, Al-Ayadhi L: Oxidative stress and antioxidant status in Saudi autistic children. Clin Biochem 2009, 42:1032-1040.

20. Al-Mosalem OA, El-Ansary A, Attas O, Al-Ayadhi L: Metabolic biomarkers related to energy metabolism in Saudi autistic children. Clin Biochem 2009, 42:949-957.

21. Kalmar B, Greensmith L: Induction of heatshockproteins for protection against oxidative stress. Adv Drug Deliv Rev 2009, 61:310-318.

22. Ran R, Lu A, Zhang L, Tang Y, Zhu H, Xu H, Feng Y, Han C, Zhou G, Rigby AC, Sharp FR: Hsp70 promotes TNF-mediated apoptosis by binding IKKY and impairing NF-KB survival signaling. Genes Dev 2004, 18:1466-1481.

23. Feinstein DL, Galea E, Reis DJ: Suppression of glial nitric oxide synthase induction by heat shock: effects on proteolytic degradation of IKB-a. Nitric Oxide 1997, 1:167-176.

24. Guzhova IV, Darieva ZA, Melo AR, Margulis BA: Major stress protein Hsp70 interacts with NF-KB regulatory complex in human T-lymphoma cells. Cell Stress Chaperones 1997, 2:132-139.

25. Curry HA, Clemens RA, Shah S, Bradbury CM, Botero A, Goswami P, Gius D: Heat shock inhibits radiation-induced activation of NF-KB via inhibition of I-kB kinase. J Biol Chem 1999, 274:23061-23067.

26. Andres D, Diez-Fernandez C, Castrillo A, Cascales M: Relationship between the activation of heat shock factor and the suppression of nuclear factor-KB activity in rat hepatocyte cultures treated with cyclosporine A. Biochem Pharmacol 2002, 64:247-256.

27. Malhotra V, Wong HR: Interactions between the heat shock response and the nuclear factor-K B signaling pathway. Crit Care Med 2002, 30:S89-595.

28. Walker SJ, Segal J, Aschner M: Cultured lymphocytes from autistic children and non-autistic siblings up-regulate heat shock protein RNA in response to thimerosal challenge. Neurotoxicology 2006, 27:685-692.

29. Lindholm D, Castrén E, Kiefer R, Zafra F, Thoenen H: Transforming growth factor-beta 1 in the rat brain: increase after injury and inhibition of astrocyte proliferation. J Cell Biol 1992, 117:395-400.

30. Buisson A, Lesne S, Docagne F, Ali C, Nicole O, MacKenzie ET, Vivien D: Transforming growth factor-beta and ischemic brain injury. Cell Mol Neurobiol 2003, 23:539-550.

31. Logan A, Berry M, Gonzalez AM, Frautschy SA, Sporn MB, Baird A: Effects of transforming growth factor beta 1 on scar production in the injured central nervous system of the rat. Eur J Neurosci 1994, 6:355-363. 
32. King VR, Phillips JB, Brown RA, Priestley JV: The effects of treatment with antibodies to transforming growth factor beta 1 and beta2 following spinal cord damage in the adult rat. Neuroscience 2004, 126:173-183.

33. Wyss-Coray T, Feng L, Masliah E, Ruppe MD, Lee HS, Toggas SM, Rockenstein EM, Mucke L: Increased central nervous system production of extracellular matrix components and development of hydrocephalus in transgenic mice overexpressing transforming growth factor-beta 1. Am J Pathol 1995, 147:53-67.

34. Frackowiak J, Mazur-Kolecka B, Kuchna I, Nowicki K, Brown WT, Wegiel J: Accumulation of Amyloid-Beta Peptide Speciesin Four Brain Structures in Children with Autism. In Proceedings of the $10^{\text {th }}$ International Meeting for Autism Research 2011(IMFAR): May 12-14, 2011; San Diego, California.

35. Al-Ayadhi LY, Ben Bacha AG, Kotb M, El-Ansary AK: A novel study on amyloid $\beta$ peptide 40,42 and $40 / 42$ ratio in Saudi autistics. Behav Brain Funct 2012, 8:4.

36. Lesne S, Docagne F, Gabriel C, Liot G, Lahiri DK, Buée L, Plawinski L, Delacourte A, Mackenzie ET, Buisson A, Vivien D: Transforming growth factor-beta 1 potentiates amyloid-beta generation in astrocytes and in transgenic mice. J Biol Chem 2003, 278:18408-18418.

37. Walsh JG, Cullen SP, Sheridan C, Lüthi AU, Gerner C, Martin SJ: Executioner caspase-3 and caspase-7 are functionally distinct proteases. Proc Natl Acad Sci U S A 2008, 105:12815-12819.

38. Erener S, Pétrilli V, Kassner I, Minotti R, Castillo R, Santoro R, Hassa PO, Tschopp J, Hottiger MO: Inflammasome-activated caspase 7 cleaves PARP1 to enhance the expression of a subset of NF-KB target genes. Mol Cell 2012, 46:200-211.

39. Garbett K, Ebert PJ, Mitchell A, Lintas C, Manzi B, Mirnics K, Persico AM: Immune transcriptome alterations in the temporal cortex of subjects with autism. Neurobiol Dis 2008, 30:303-311.

40. Tostes MH, Teixeira HC, Gattaz WF, Brandão MA, Raposo NR: Altered neurotrophin, neuropeptide,cytokines and nitric oxide levels in autism. Pharmacopsychiatry 2012, 45:241-243.

\section{doi:10.1186/1742-2094-9-265}

Cite this article as: El-Ansary and Al-Ayadhi: Neuroinflammation in autism spectrum disorders. Journal of Neuroinflammation 2012 9:265.

\section{Submit your next manuscript to BioMed Central and take full advantage of:}

- Convenient online submission

- Thorough peer review

- No space constraints or color figure charges

- Immediate publication on acceptance

- Inclusion in PubMed, CAS, Scopus and Google Scholar

- Research which is freely available for redistribution 